Antal Nagy, Janos Kundrak, Miskolc, Hungary

\title{
INVESTIGATION OF SURFACE ROUGHNESS CHARACTERISTICS OF FACE MILLING
}

\begin{abstract}
Surface quality and accuracy affect the integrity and lifetime of machine parts and the operational requirements of the structural (or assembly) units. These are the reasons that the expected surface roughness must be planned based on the operational requirements of the parts. The path of the tool edge, which is defined by the characteristics of the kinematics of face milling, makes the milled surface inhomogeneous, which means the roughness analysis in various directions gives different values. In this paper the effect of increasing the feed rate on surface roughness is investigated. This cutting data is chosen because increasing the feed rate is an effective way to increase productivity.

Keywords: face milling; cutting forces; depth of cut; cutting speed; rectangular inserts.
\end{abstract}

\section{INTRODUCTION}

The purpose of finishing parts is to meet the roughness and accuracy requirements of the part drawing. Extensive research work is being carried out to achieve surface roughness values that meet the operational requirements, including in face milling. A great number of publications describe the results; some of their conclusions are presented in the followings.

Mansour et al. [1] aimed to discover the relationship between cutting data and surface roughness characteristics with three independent variables $\left(\mathrm{v}_{\mathrm{c}}, \mathrm{f}_{\mathrm{z}}\right.$ and $\left.\mathrm{a}_{\mathrm{p}}\right)$ with dry machining. They found that when increasing the cutting data, surface roughness decreases with the cutting speed $\left(\mathrm{v}_{\mathrm{c}}\right)$ and increases with the axial depth-of-cut $\left(\mathrm{a}_{\mathrm{p}}\right)$ and the feed rate $\left(\mathrm{f}_{\mathrm{z}}\right)$. It is concluded that the same roughness value can be achieved with the appropriate combination of cutting speed and feed rate, thus by applying higher speeds the machining time can be reduced, also the material removal rate can be increased.

Sheth et al. [2] also studied the effect of cutting data on surface roughness with full factorial design. It was concluded that the surface roughness is influenced slightly by the cutting speed $v_{c}$ and the depth-of-cut $a_{p}$ but the lowest value should be sought to keep the feed rate $f_{z}$ low. They found that changing the parameters in couples affects the surface roughness in different ways: significantly for $\mathrm{v}_{\mathrm{c}}-\mathrm{f}_{\mathrm{z}}$; it has a small effect on $\mathrm{v}_{\mathrm{c}}-\mathrm{a}_{\mathrm{p}}$; and it has no effect on $\mathrm{f}_{\mathrm{z}}-\mathrm{a}_{\mathrm{p}}$.

Liu et al. [3] investigated how surface roughness affects the fatigue life of the part. It was found that the roughness is most dependent on the feed rate, while the cutting speed has small, and the depth-of-cut has very little effect. Significant differences in roughness values were experienced on different parts of the surface of the samples. 
A mathematical model was further developed by Baek et al. [4] to calculate surface roughness. It takes into consideration the run-out of inserts, which is inevitable when manufacturing tools. It has been observed that the effect of the run-out on the surface roughness is not directly proportional to the feed rate, therefore the run-out is always recommended to be pre-measured for surface roughness estimation.

Ozcelik [5] found during experiments cutting with the same tool that with the increase of tool wear, the roughness of the machined surface increases. The amount of the wear was correlated with the machining time, which is easy to determine. Taking the wear into account, a formula was developed to determine the Ra value more accurately. As a result of his experiment, the factors affecting roughness were stated in descending order: cutting time, depth-of-cut, cutting speed, and feed rate.

Zhao et al. [6] also listed the factors affecting the roughness in descending order: feed rate, depth-of-cut, and cutting speed.

A study was conducted to determine how two- and three-dimensional surface roughness parameters are formed when separating a constant chip cross section with one or several chips as a function of $\mathrm{a}_{\mathrm{p}} / \mathrm{f}_{\mathrm{z}}$ chip size ratio [7]. It was found that by increasing the feed per tooth $\mathrm{f}_{\mathrm{z}}$ for face milling with a single insert the roughness of the plane surface is gradually deteriorates. For the cutting experiment with five inserts, the result of 4 to 5 times higher roughness can be explained by the run-out of the inserts.

Preliminary estimation of surface roughness of machined surfaces is also an important research direction. The effect of the run-out was studied by a suitable method to determine the theoretical values of surface roughness and to estimate the expected roughness of the surfaces machined under the given conditions, with circular inserts [8]. It was concluded that the roughness of the machined surface - for the tested settings was 1.44-7.71 times worse when made with several inserts, depending on the feed rate, than when made with a tool which has no run-out.

Based on this short literature review it seems that the facts influencing the surface roughness and the intensity of these effects are judged differently in terms of various cutting conditions (tool-workpiece material pairing, technological parameters). In this paper the change of 2D and 3D surface roughness parameters as a function of feed rate is investigated for symmetric face milling. Because of the significant changes in the depth-of-cut $a_{p}$ and the feed rate $f_{z}$, the characteristics of the chip separation and deformation also varies, so the change of the chip size ratio $\mathrm{a}_{\mathrm{p}} / \mathrm{f}_{\mathrm{z}}$ has also been analyzed in relation to the surface roughness.

\section{EXPERIMENTAL CONDITIONS}

The experiments were performed on a Perfect Jet MCV-M8 vertical milling machine. The tool was a Sandvik R252.44-080027-15M face milling head having a nominal diameter of $\mathrm{D}_{\mathrm{t}}=80 \mathrm{~mm}$. During cutting, only one insert was used, which was Sandvik R215.44-15T308M-WL rectangular coated carbide grade with a cutting edge angle of $\kappa_{\mathrm{r}}=90^{\circ}$. Other details: $\gamma_{\mathrm{o}}=0^{\circ} ; \alpha_{0}=11^{\circ} ; \mathrm{r}_{\varepsilon}=0.8 \mathrm{~mm}$. 
The workpieces used for the experiments were made of $\mathrm{C} 45$ grade unalloyed steel (material number: 1.0503) in normalized condition, which has the tensile strength 580 MPa and Brinell hardness $207 \mathrm{HBW}$ [9]. The surfaces prepared on the specimens for milling were $58 \mathrm{~mm}$ in length and $50 \mathrm{~mm}$ in width.

The cutting data used for the experiments are contained in Table 1. The specimens were produced of one material, plane surfaces were milled in symmetric setting with several $f_{z}$ feed rates in total width while keeping the $v_{c}$ cutting speed and the $a_{p}$ depth-of-cut constant. Each sample was machined with a fresh cutting edge.

Table 1 - Cutting data for the experiments

\begin{tabular}{|c|c|c|c|c|}
\hline No. & $\mathrm{v}_{\mathrm{c}}[\mathrm{m} / \mathrm{min}]$ & $\mathrm{ap}_{\mathrm{p}}[\mathrm{mm}]$ & $\mathrm{f}_{\mathrm{z}}[\mathrm{mm}]$ & $\mathrm{a}_{\mathrm{p}} / \mathrm{f}_{\mathrm{z}}$ \\
\hline 1 & \multirow{5}{*}{400} & \multirow{5}{*}{0.4} & 0.1 & 4 \\
\hline 2 & & & 0.2 & 2 \\
\hline 3 & & & 0.4 & 1 \\
\hline 4 & & & 0.8 & 0.5 \\
\hline 5 & & & 1.6 & 0.25 \\
\hline
\end{tabular}

The 2D and 3D roughness measurements were carried out using an AltiSurf 520 three-dimensional surface roughness measuring device. A CL2 confocal chromatic optical sensor equipped with a MG140 magnifier was used for the recordings. The probe has the axial resolution of $0.012 \mu \mathrm{m}$ and the horizontal steps are at least $0.5 \mu \mathrm{m}$. The evaluations were performed with AltiMap Premium software.

The measurements were carried out in the symmetry plane and in two parallel planes at the same distance from the first one. The starting positions and the places of the measurements are shown in Figure 1. The lengths of the longitudinal measurements were the same as those instructed by standards ISO 4287 and ISO 4288. Each 3D measurement had an area of $2.5 \times 2.5 \mathrm{~mm}$.

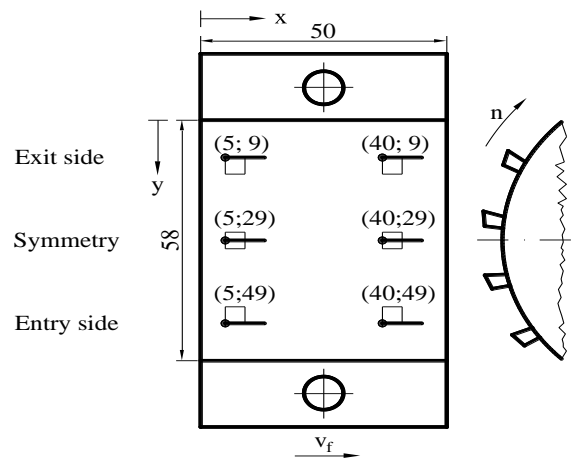

Figure 1 - Positions of the measurements 


\section{RESULTS OF EXPERIMENTS}

Of the known 2D roughness parameters only $\mathrm{Ra}$ and $\mathrm{Rz}$ values are given, as in practice these occur most frequently. Table 2 shows the values of the measurement results. The feed rate values were assigned in geometric series. The arithmetic mean roughness $\mathrm{Ra}$ and the maximum roughness depth $\mathrm{Rz}$ values progressively increase by increasing the feed rate between the two neighboring values, and with it chip size ratio decreases. During the increase in feed per tooth, the change in both roughness parameters is the highest in the symmetry plane: Ra increased 59.5 times and $\mathrm{Rz}$ increased 43.6 times. With $f_{z}=0.1$ feed per tooth there is little difference between the values measured in the planes but when increasing the feed rate - or reducing the chip size ratio - the differences become larger. At lower feed rates it can be observed that the roughness values - both $\mathrm{Ra}$ and $\mathrm{Rz}$ - measured in the symmetry plane are the smallest of the planes; however, at $\mathrm{f}_{\mathrm{z}}=0.4$ and larger values this relationship is reversed.

Table $2-2 D$ Surface roughness values for various feed rates

\begin{tabular}{|l|l|l|l|l|l|l|l|l|}
\hline $\mathrm{N}$ & \multirow{2}{*}{$\begin{array}{l}* \\
\mathrm{o} .\end{array}$} & $\mathrm{f}_{\mathrm{z}}$ & $\mathrm{a}_{\mathrm{p}} / \mathrm{f}_{\mathrm{z}}$ & \multicolumn{2}{l}{ Ra $[\mu \mathrm{m}]$} & \multicolumn{2}{l|}{ Rz $[\mu \mathrm{m}]$} \\
\cline { 4 - 9 } & & & Entry & Middle & Exit & Entry & Middle & Exit \\
\hline 1 & 0.1 & 4 & 0.325 & 0.322 & 0.350 & 1.934 & 1.510 & 1.817 \\
\hline 2 & 0.2 & 2 & 0.743 & 0.645 & 0.703 & 3.591 & 3.017 & 3.845 \\
\hline 3 & 0.4 & 1 & 1.752 & 2.904 & 1.229 & 6.492 & 10.200 & 6.878 \\
\hline 4 & 0.8 & 0.5 & 6.440 & 7.835 & 4.032 & 23.862 & 29.313 & 16.739 \\
\hline 5 & 1.6 & 0.25 & 16.486 & 19.159 & 9.115 & 49.914 & 65.849 & 38.636 \\
\hline
\end{tabular}

As we have analyzed the $\mathrm{Ra}$ and $\mathrm{Rz}$ values from the possible parameters, values of $\mathrm{Sa}$ and $\mathrm{Sz}$ are taken from the 3D measurements. The measured values are shown in Table 4 . The characteristics of the values between the measuring planes and the change in the feed rate is the same as in the $2 \mathrm{D}$ case. The symmetry plane shows the maximum change in roughness values here as well, but the ratios are smaller in both cases. They are 41.8 times higher for $\mathrm{Sa}$ and 26.5 times higher for $\mathrm{Sz}$.

Table 3 - 3D Surface roughness values for various feed rates

\begin{tabular}{|c|c|c|c|c|c|c|c|c|}
\hline \multirow{2}{*}{ No. } & \multirow{2}{*}{$\mathrm{f}_{\mathrm{z}}$} & \multirow{2}{*}{$\mathrm{a}_{\mathrm{p}} / \mathrm{f}_{\mathrm{z}}$} & \multicolumn{3}{|c|}{$\mathrm{Sa}[\mu \mathrm{m}]$} & \multicolumn{3}{|l|}{$\mathrm{Sz}[\mu \mathrm{m}]$} \\
\hline & & & Entry & Middle & Exit & Entry & Middle & Exit \\
\hline 1 & 0.1 & 4 & 0.396 & 0.371 & 0.392 & 2.522 & 2.509 & 2.596 \\
\hline 2 & 0.2 & 2 & 0.767 & 0.631 & 0.695 & 3.493 & 3.273 & 4.317 \\
\hline 3 & 0.4 & 1 & 2.406 & 2.920 & 1.708 & 11.966 & 12.108 & 11.994 \\
\hline 4 & 0.8 & 0.5 & 5.288 & 7.681 & 4.787 & 25.901 & 33.239 & 26.102 \\
\hline 5 & 1.6 & 0.25 & 11.156 & 15.521 & 12.371 & 59.200 & 66.478 & 66.346 \\
\hline
\end{tabular}


The roughness profile curves are shown in Figure 2, arranged according to the measuring planes and the feed per tooth. All curves show the periodicity well. On some graphs two peaks are visible per period, which shows the cutting edge and the minor cutting edge impressions together.

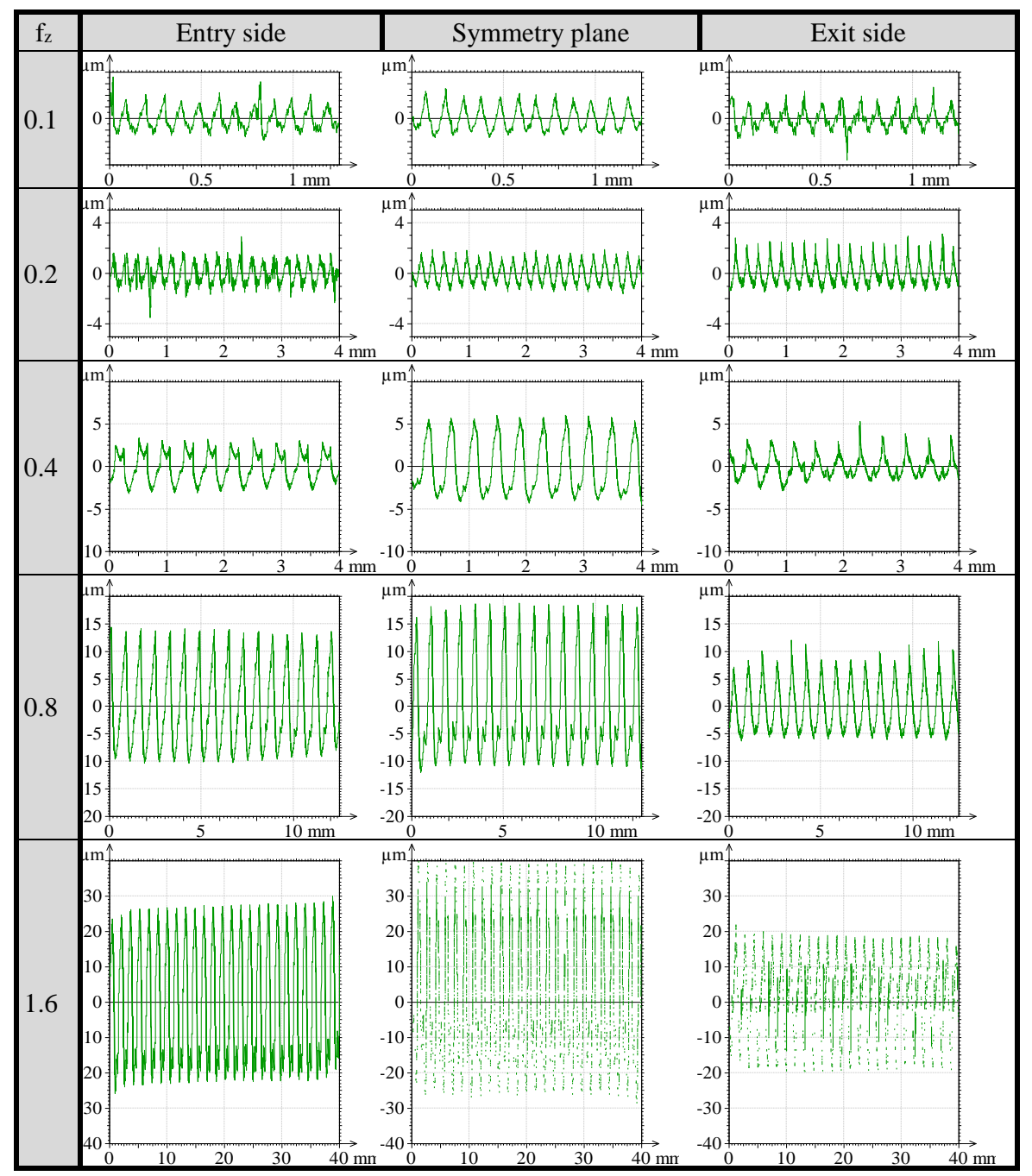

Figure $2-2 \mathrm{D}$ roughness profile curves of the milled surface at different feed rates 
The mappings of the surfaces can be seen in Figure 3. On the topographies the typical roughness impressions can be noticed well. While only the roughness profile of the machined surface appears in the symmetry plane, on the entry side the scratching of the minor cutting edge is also visible on the surface. It is also noticeable on the exit side, with much deeper grooves appearing here. This is also related to the different values between the planes.

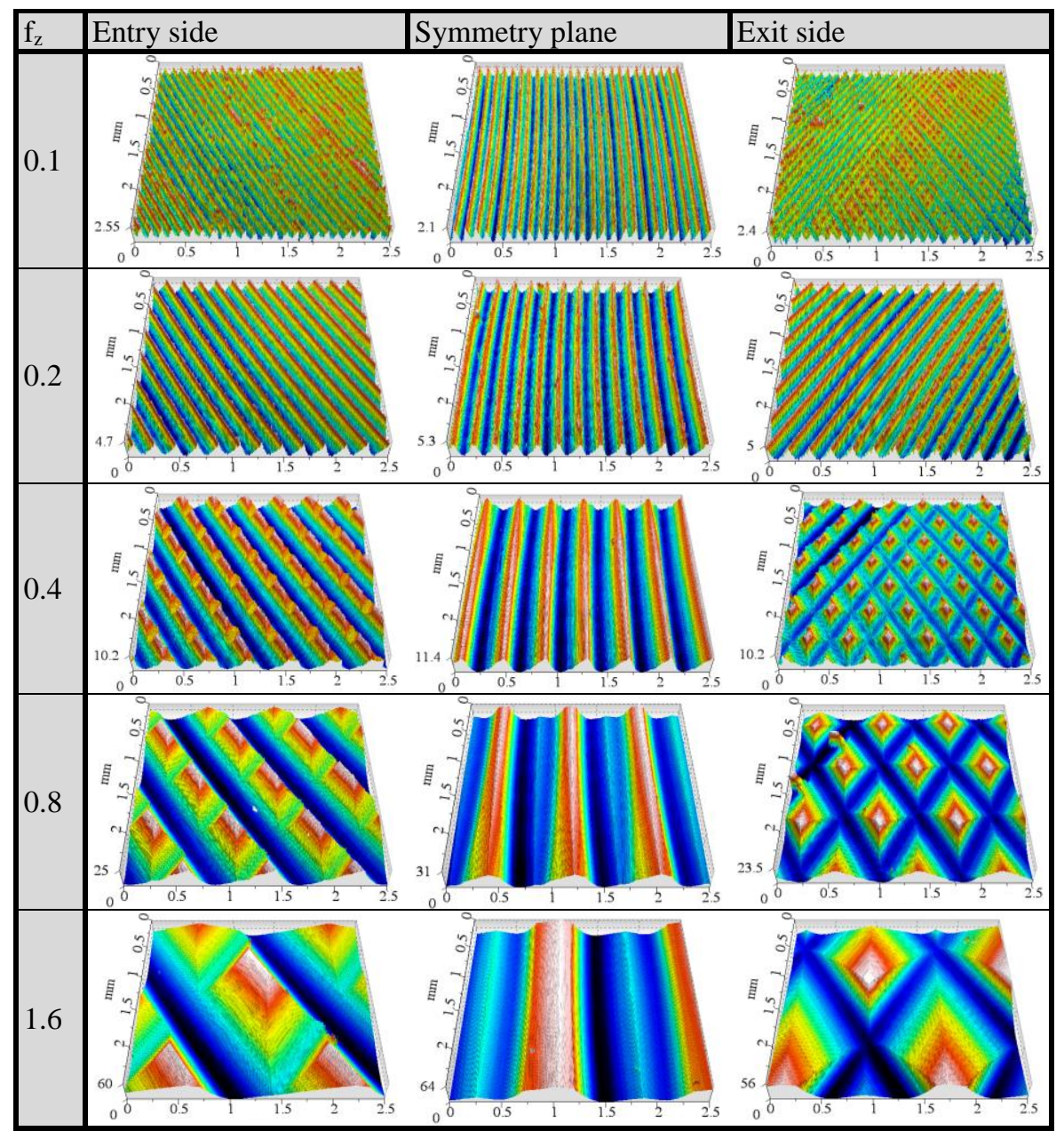

Figure 3 - Topography of the measured surfaces 


\section{DISCUSSIONS}

The measured values presented in the above tables are shown in diagrams, which make the analysis of the results more meaningful and facilitate their evaluation.

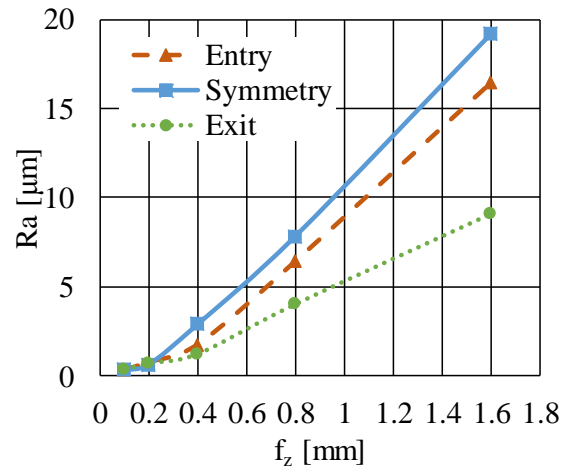

a)

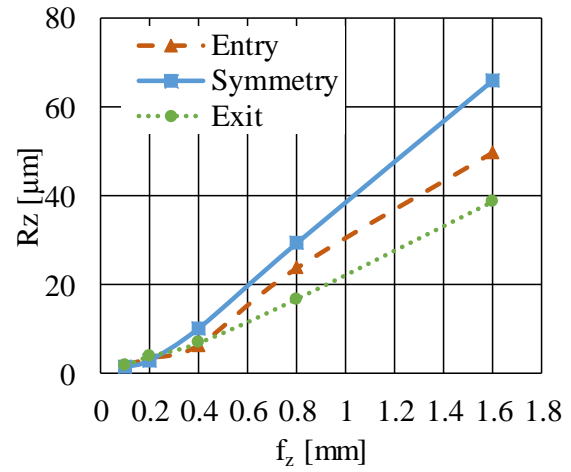

b)

Figure 4 - Measurement results as a function of $\mathrm{f}_{\mathrm{z}}$ feed rate

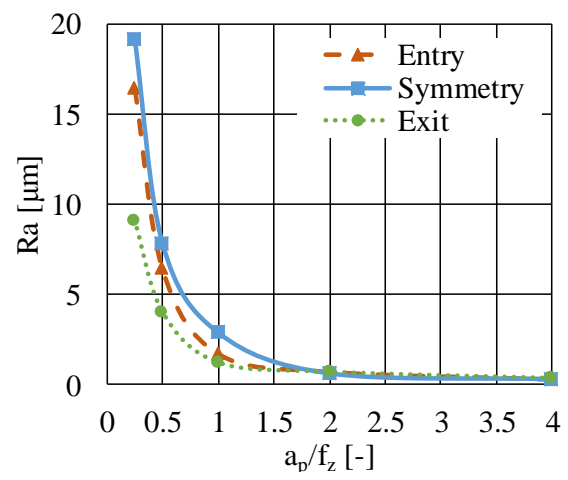

a)

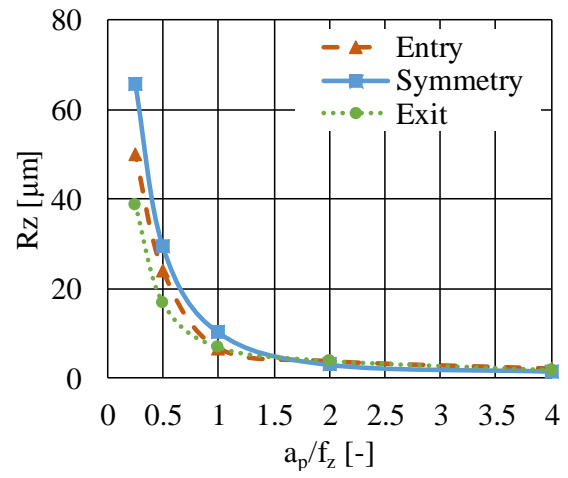

b)

Figure 5 - Measurement results as a function of $\mathrm{a}_{\mathrm{p}} / \mathrm{f}_{\mathrm{z}}$ chip size ratio

Figure 4 shows the $2 \mathrm{D}$ roughness parameters as a function of feed rate. It can be stated that only increasing the feed rate makes the roughness values increase almost linearly. Looking at the curves of the diagrams, it can be seen that the roughness values differ in the three measured planes. At low feed rates $\left(f_{z}=0.1 \ldots 0.2\right)$ roughness values are close to each other, and when using higher feed rates $\left(f_{z} \geq 0.4\right)$ the difference of the values between planes is also higher. 
Figure 5 shows the $\mathrm{Ra}$ and $\mathrm{Rz}$ roughness values set for the chip size ratio. Theoretically, the highest values of roughness should be found in the symmetry plane, however the measured values follow this tendency only at $a_{p} / f_{z}$ less than 1 . When setting higher depth-of-cut and lower feed rate $\left(a_{\mathrm{p}} / \mathrm{f}_{\mathrm{z}}>1\right)$ the differences between the three planes are very small. This suggests that the assumption that it is sufficient to measure the maximum roughness in the symmetry plane is not verified in all cases.

3D roughness parameters show similar changes that can be seen well in Figures 6 and 7. As described in the profile diagrams, the differences in the profiles of the three planes cause different values between the planes.

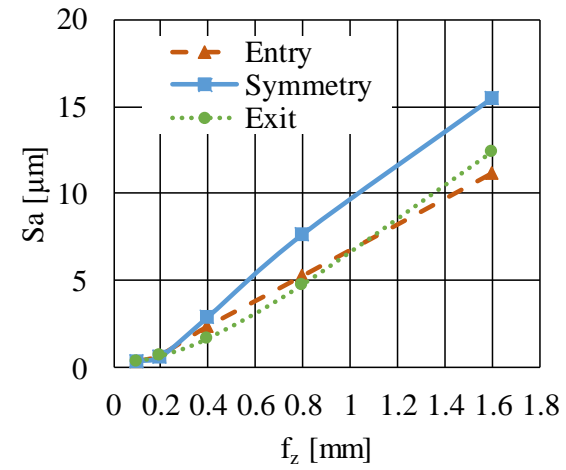

a)

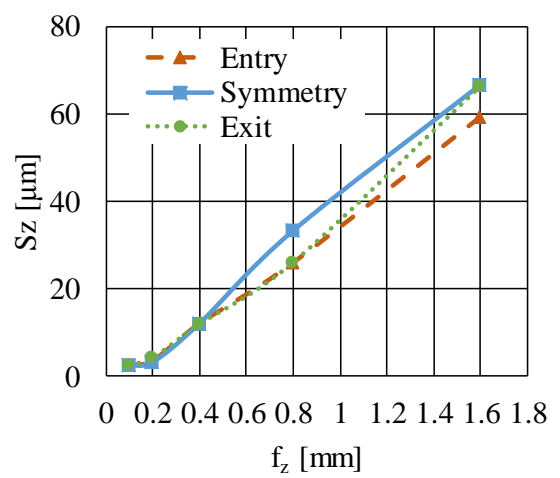

b)

Figure $6-3 D$ surface roughness values as a function of $f_{z}$ feed rate

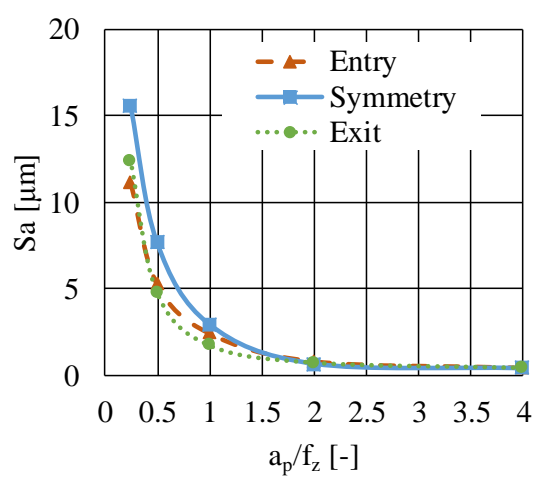

a)

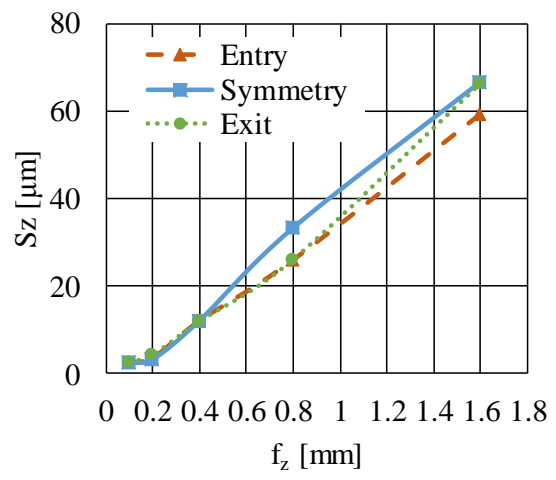

b)

Figure $7-3 D$ surface roughness values as a function of $a_{\mathrm{p}} / \mathrm{f}_{\mathrm{z}}$ chip size ratio 


\section{CONCLUSIONS}

For face milling it is necessary to consider that surface roughness is inhomogeneous due to the motion of the tool edge; therefore, the values of the roughness parameters differ when measuring the surface in different directions and in planes and various surface elements.

In this article, symmetrical face milling was performed on unalloyed steel, with a milling head equipped with only one rectangular insert, where the feed per tooth $f_{z}$ was changed and the depth-of-cut $a_{p}$ and the cutting speed $v_{c}$ were kept constant. The surface roughness of the milled specimens was measured in three parallel planes, and the $2 \mathrm{D}$ and $3 \mathrm{D}$ values of the parameters were analyzed and evaluated. During the analysis, the following conclusions were made.

For the $a_{\mathrm{p}} / \mathrm{f}_{\mathrm{z}}$ chip size ratio the setting of higher depth-of-cut and lower feed rate causes very little change in roughness values. However, if a ratio of $a_{\mathrm{p}} / \mathrm{f}_{\mathrm{z}} \leq 1$ is set, following the change the values of the roughness parameters increase significantly. Therefore, when choosing the $\mathrm{a}_{\mathrm{p}} / \mathrm{f}_{\mathrm{z}}$ ratio it is recommended to pay particular attention to the change in roughness values in the steeply increasing section (Fig. 4.b) so that the roughness values given in the part drawing are not exceeded.

The maximum surface roughness values were not always measured in the symmetry plane, which indicates that the maximum roughness can be measured at different points of the surface. It is therefore recommended to check the surface roughness for correct evaluation not only in the symmetry plane but also in parallel planes.

While in theory [10] the planes of the same distance to the symmetry plane are identical to the roughness values, this was not proven during the experiments. The experimental results gave larger values on the entry side than on the exit side. The explanation for this is that up-milling is realized from the entry side until the middle plane, and then down-milling occurs up to the exit side [11].

\section{ACKNOWLEDGEMENTS}

The authors greatly appreciate the support of the National Research, Development and Innovation Office - NKFIH (No. of Agreement: K 116876).

The described study was carried out as part of the EFOP-3.6.1-16-00011 "Younger and Renewing University - Innovative Knowledge City - institutional development of the University of Miskolc aiming at intelligent specialization" project implemented in the framework of the program Szechenyi 2020.

Both grants are gratefully acknowledged.

References: 1. Mansour, A., Abdalla, H.: Surface roughness model for end milling: a semi-free cutting carbon casehardening steel (EN32) in dry condition, Journal of Materials Processing Technology 124 (2002) pp.183-191; 2. Sheth, S., George, P.M.: Experimental Investigation and Prediction of Flatness and Surface Roughness during Face Milling Operation of WCB Material, Procedia Technology 23 (2016) pp.344-351; 3. Liu, G., Huang, C., Zhu, H., Liu, Z., Liu, Y., Li, C.: The modified surface properties and 
fatigue life of Incoloy A286 face-milled at different cutting parameters, Materials Science \& Engineering A 704 (2017) pp.1-9; 4. Baek, D.K., Ko, T.J., Kim, H.S.: Optimization of feedrate in a face milling operation using a surface roughness model, International Journal of Machine Tools \& Manufacture 41 (2001) pp.451462; 5. Ozcelik, B., Bayramoglu, M.: The statistical modeling of surface roughness in high-speed flat end milling, International Journal of Machine Tools \& Manufacture 46 (2006) pp.1395-1402; 6. Zhao, G., Guo, Y.B., Zhu, P., Zhao, Y.: Energy Consumption Characteristics and Influence on Surface Quality in Milling, Procedia CIRP 71 (2018) pp.111-115; 7. Kundrák, J., Felhö, C.: Investigation of the topography of face milled surfaces, Materials Science Forum 919 (2018) pp.78-83; 8. Felho, C.; Kundrak, J.: Effects of Setting Errors (Insert Run-Outs) on Surface Roughness in Face Milling When Using Circular Inserts, Machines vol.6 issue:2 (2018) Article Number: 14.; 9. European Steel and Alloy Grades/Numbers, C45, http://www.steelnumber.com/en/steel_composition_eu.php?name_id=152; 10. Felho, C., Karpuschewski, B., Kundrák, J.: Surface roughness modelling in face milling, Procedia CIRP 31 (2015) pp. 136-141; 11. Shaw, M.C.: Metal Cutting Principles. Calendron Press, Oxford. 1984.

\title{
Антал Надь, Янош Кундрак, Мішкольц, Угорщина
}

\section{ДОСЛІДЖЕННЯ ХАРАКТЕРИСТИК ШОРСТКОСТІ ПОВЕРХНІ ПРИ ТОРЦЕВОМУ ФРЕЗЕРУВАННІ}

\begin{abstract}
Анотація. Якість і точність поверхні впливають на иілісність і термін служби деталей машин, а також на експлуатаційні вимоги конструкиійних (або монтажних) вузлів. Це є причиною того, що очікувана шорсткість поверхні повинна бути запланована на основі експлуатаційних вимог до деталей. Шлях кромки інструменту, який визначається характеристиками кінематики ториевого фрезерування, робить фрезеровану поверхню неоднорідною, щя означає, щуо аналіз шорсткості в різних напрямках дає різні значення. Досліджено вплив збільшення величини подачі на шорсткість поверхні. Ці дані для різання вибираються тому, що збільшення величини подачі є ефективним способом підвищення продуктивності. Виходячи з огляду літератури, здається, щуо факти, щуо впливають на шорсткість поверхні та інтенсивність деяких ефектів, оцінюються по-різному з точки зору різних умов різання (склад матеріалу заготовки, технологічні параметри). У иій роботі досліджено зміну параметрів шорсткості $2 D$ та $3 D$ поверхні як функція величини подачі симетричного ториевого фрезерування. Внаслідок значних змін глибини різання $і$ величини подачі, характеристики поділу та деформації мікрочастин також змінюються. Для ториевого фрезерування необхідно враховувати, шео шорсткість поверхні неоднорідна внаслідок особливостей руху крайки інструмента; отже, значення параметрів шорсткості відрізняються при вимірюванні $i$ в різних напрямках $i$ в площинах $i$ різних поверхневих елементах. У иій статті було проведено симетричне фрезерування тория заготовки з нелегованої сталі, фрезерною головкою, обладнаною тільки однією прямокутною вставкою, де змінювалася подача на зуб, а глибина різання і швидкість різання зберігалися постійними. Шорсткість поверхні оброблених зразків вимірювали у трьох паралельних площинах, аналізували та очінювали $2 D$ та $3 D$ значення параметрів.
\end{abstract}

Ключові слова: ториеве фрезерування; сили різання; глибина різання; швидкість різання; прямокутні вставки. 